Yüzüncü Yil Üniversitesi
Tarim Bilimleri Dergisi

Derleme Makalesi (Review Article)

\title{
Van İli Buğday Tarımının Türkiye ve Bölgedeki Yeri, Sorunları ve Çözüm Önerileri
}

\section{Fevzi ALTUNER ${ }^{* 1} \quad$ Erol ORAL ${ }^{2}$ Mehmet ÜLKER ${ }^{2}$}

${ }^{1}$ Van Yüzüncüyıl Üniversitesi, Gevaş MYO, Bitkisel ve Hayvansal Üretim Bölümü, Van, Türkiye

${ }^{2}$ Van Yüzüncüyıl Üniversitesi, Ziraat Fakültesi, Tarla Bitkileri Bölümü, Van, Türkiye

*fevzialtuner@yyu.ed.tr

\section{Makale Bilgileri}

Geliş: 11.12.2018

Kabul: 24.05.2019

Online Yayinlanma 28.06.2018

DOI: 10.29133/yyutbd.495652

\section{Anahtar kelimeler}

Buğday tarımı,

Çözüm önerileri,

Sorunlar,

Van
Öz: Van Il'’inde 787314 da alanda buğday ekilişi yapılmakta, karşıllğında 10444 bin ton üretim ve $1326 \mathrm{~kg} / \mathrm{da}$ verim alınmaktadır. Bu verim Türkiye'de alınan verimin $(280 \mathrm{~kg} / \mathrm{da})$ yarısına denk gelmektedir. İl'de verimin Türkiye ortalaması seviyesine çıkarılabilmesi halinde buğday tarımı için ayrılan alanın yarısı kadar bir alanda aynı miktarda üretim yapmak mümkün olacaktır. Verim düşüklüguünün başlıca sebebi İl'de buğday tarımında yüksek verimli ve kaliteli tescilli çeşitlerin yerine genel olarak yöresel çeşitlerin kullanılmasıdır. Yöresel çeşitler un sanayiinde de tercih edilmediği için sektör ihtiyaç duyduğu hammaddenin \% 80 'ini il dışından temin etmektedir. Bununla birlikte çok parçalı ve küçük ölçekli işletme yapısı, traktör ve ekipman mevcudunun Türkiye ortalamasından düşük olması, nadas alanlarının çokluğu, yetiştiricilikte teknik bilgi ve materyal eksikliği gibi bir takım sorunlar da İl'de buğday yetiştiriciliğinin önündeki engeller olarak görülmektedir. Bu engellerin bertaraf edilerek verim ve kalitenin arttrrlabilmesi için uygulanacak bazı tedbirler, buğday üretiminde ilgili her kesimin tatmin olabileceği sonuçlar ortaya çıkaracaktır.

\section{Place in Turkey and Region of Wheat Agriculture İn Van Province, Problems and Solutions}

\section{Article Info}

Received: 11.12 .2018

Accepted: 24.05.2019

Online Published 28.06.2018

DOI: $10.29133 /$ yyutbd.495652

\section{Keywords}

Wheat cultivation,

Solutions,

Problems,

Van

\begin{abstract}
In the province of Van, wheat cultivation has made in the 787314 da area, and in return has produced 10444 thousand tons of production and has obtained $1326 \mathrm{~kg} / \mathrm{da}$ yield. This corresponds to half of the yield in Turkey (280 $\mathrm{kg} / \mathrm{da}$ ). If the yield in te province can be increased to average of Turkey,the same production would be possible to produce in half amount of area. The main reason for the decrease in productivity in province is the use of local varieties instead of high-efficiency and high quality registered varieties in wheat agriculture. Since the local varieties has not preferred in the flour industry, the sector supplies $80 \%$ of the raw material needed from outside the province. However, very fragmented and small-scale agricultural business structure, tractors and equipment is lower than Turkey's average current, the plurality of fallow fields, such as technical information and material deficiency in production of some problems, is seen as the obstacles of wheat cultivation in the province. Some measures to be taken in order to eliminate these obstacles and increase the yield and quality will result that every relevant sector can be satisfied in wheat production.
\end{abstract}




\section{Giriş}

Buğday, tüm Dünya'da insan beslenmesinde kullanılan temel besinlerin hammaddesi olduğundan diğer tarımsal ürünlere göre daha büyük bir öneme sahiptir. Buğday günlük ekmeğin hammaddesi ve Dünya üzerinde 50 ülkenin temel besin maddesidir. $\mathrm{Bu}$ yönüyle buğday Dünya nüfusunun \% 35'inin besin ihtiyacını ve günlük kalorinin \% 20'sini karşılamaktadır (Kaya ve ark., 2015). Dünya'da 7183 milyon ha alanda tahıl ekilişine karşılık 28466 milyon ton tahıl üretimi yapılmakta ve bunun 2204 milyon ha alanında gerçekleştirilen buğday ekilişine karşıllık 7290 milyon ton buğday ve $33074 \mathrm{~kg} / \mathrm{da}$ verim elde edilmektedir (Anonim, 2014a). Türkiye'de buğday ve buğdaydan elde edilen gıda maddelerinin insan beslenmesinde ilk sırayı alması nedeniyle önemi daha da artmaktadır. Türkiye 'de günlük kalori ihtiyacının \%53'ü ekmek ve öteki buğday ürünlerinden temin edilmektedir. Dünya buğday ekim alanlarının \% 3.5' ini Türkiye oluşturmaktadır. Türkiye'de nadas alanları haricindeki tarım alanlarının \% 66.4' ünde (15.5 milyon) tarla ziraatı yapılmaktayken bunun \% 71'inde (11.1 milyon ha) hububat tarımı yapılmaktadır. Hububat ekilişlerinde \% 69'luk payla (7.6 milyon ha) buğday ilk sırada bulunmaktadır. 1930 yılında 2.8 milyon ha alanda 2.6 milyon ton üretim ve $921 \mathrm{~kg} / \mathrm{ha}$ verim elde edilmişken 2000 yılında 3.4 kat artışla 9.4 milyon ha ekim alanında 21 milyon ton üretim ve $2234 \mathrm{~kg} /$ ha buğday verimi alınmıştır. 2017 yılı Türkiye buğday ekim alanı 7.6 milyon ha, üretimi 21.5 milyon ton, verimi ise $280 \mathrm{~kg} / \mathrm{da}$ şeklinde gerçekleşmiştir (Anonim, 2018a). Türkiye'de buğday veriminde yıllar itibariyle artış sağlanmasıyla beraber, ortalaması Dünya veriminin altındadır. Birim alandan alınan tane verimini yükselterek üretim artış1 sağlanması için yetiştirme tekniği uygulamalarında yapılacak iyileştirmeler, uygun çeşit ve nitelikli tohumluk kullanımı, fiyat ve pazarlama sorunlarının çözülmesi ve kayıpların azaltılması ile ülkemiz, tahıllarda 20 yılda kendine yeter duruma gelip aynı zamanda ciddi miktarda ihracat da gerçekleştirebilecektir (Şehirali ve ark., 2000).Verimin artırılabilmesi için farklı ancak birbirinden ayrılmaz bazı önemli kavramlar vardır. Roth ve arkadaşları tarafindan 1984 yılında yapılan bir araştırmaya göre, verimdeki artışların ya genetik potansiyelin artırılması ya da verimi sınırlayan olumsuz faktörlerin azaltılmasıyla sağlanabileceği, verimdeki \% 100'lük bir artışın, \% 60'ının yüksek verimli yeni sslah çeşitlerinin, \% 40'ının ise kültürel uygulamalardaki gelişmelerin bir yansıması olduğu belirlenmiştir (Kaya ve ark., 2015). Uygun yetiştirme tekniklerinin ve verim kabiliyeti yüksek çeşitlerin kullanımı birim alandan daha yüksek verim alabilmenin koşulları olarak bilinmekte ve özellikle kuru tarım sisteminde uygun çeşit seçiminin verimi \% 20-30 oranında arttırdığ 1 kabul edilmektedir (Kün ve ark., 1995). Türkiye’de buğday üretiminde kullanılan 8 milyon ha civarındaki alan dikkate alındığı zaman $20 \mathrm{~kg} / \mathrm{da}$ civarında tohum kullanımına dayalı olarak yıllık 1.6 milyon ton civarında tohumluk ihtiyacı bulunduğu ortaya çıkmaktadır. Buğday kendine döllenen bir bitki olduğundan ekilen tohumların 3 yılda bir sertifikalı tohumluklarla yenilenmesi ihtiyaci nedeniyle yaklaşık olarak her yıl 540 bin ton sertifikalı buğday tohumluğu kullanılması gerekmektedir. Buna karşılık ülkemizde 2007 yılında üretilen sertifikalı tohum miktarı 210 bin ton iken 2017 yılında 508 bin tona ulaşmıştır (Anonim, 2018a). Bu yönüyle ülkemizde üretimin sertifikalı tohumluk ihtiyacını karşıladığını söylemek mümkündür. 2017 yılında Doğu Anadolu Bölgesi’nde Türkiye'nin \% 7'sine karşılık gelen 1.15 milyon ton buğday üretimi yapılmıştır (Anonim, 2018a) . Bu üretim tamamen sertifikalı tohumluk kullanılarak elde edilmemiştir. Tescilli çeşitler, yerel çeşitlerden iki kat daha verimli olduğu halde Doğu Anadolu Bölgesinde \% 75 düzeyinde yerel çeşitler yetiştirilmektedir (Olgun ve ark., 1998). Düşük verimli yerel çeşitlerin kullanımı, bölgede buğdayda tane verim düşüklüğünün nedenlerinden biri olarak bilinmektedir. (Olgun ve ark., 1999). Tahıllarda değerleri bitki sıklığına göre değişen birim alandaki fertil başak sayısı, başakta tane sayısı ve başakta tane verimi gibi unsurlar birim alan tane verimine doğrudan etki etmektedir. Bu nedenle çeşit ve ekolojiye göre birim alana atılacak tohum miktarı ve bunun yeknesak biçimde araziye dağılımı, her bitki için ihtiyaç duyulan optimum alanın temini açısından oldukça önemlidir. Bu sağlandığı ölçüde birim alan tane verimi de artmaktadır (Kaydan ve ark., 2011). Ülkemizde olduğu gibi Van İli' nde de buğday insan beslenmesinde çok önemli bir yere sahip olup, Van Gölü çevresinde üretimi en fazla yapılan tahıl cinsidir (Kaydan ve ark., 2011). Van gölü havzasında buğday tarımında daha çok karışık bir populasyon niteliğinde olan tir buğdayı tercih edilmektedir (Doğan ve ark., 1980; Kaydan ve Yağmur, 2008). Tir buğdayı pek çok özellik bakımından geniş bir varyasyon göstermektedir (Sönmez ve ark., 1999) ve kendi ekolojisinde yüksek bir verim potansiyeline sahiptir (Doğan ve ark., 1980; Yılmaz 1989; Yılmaz ve ark., 1994). Van İlinde 371182 ha tarım arazisine karşılık 787314 da alanda buğday 
tarımı yapılmakta, bu alandan 104440 ton ürün ve $1326 \mathrm{~kg} / \mathrm{da}$ verim elde edilmektedir (Anonim, 2016). Soğuk ve kurak karasal iklimin etkilerinin yoğun olarak görüldüğü Van İli’nde arazilerin çok parçalı oluşu, tarımsal faaliyetlerde gerekli teknik bilgi yetersizliği, tarımsal girdi ve modern teknolojinin yeterince kullanılmaması, yüksek verim potansiyeline sahip tescilli çeşitlerin kullanımının yetersiz olması, çiftçinin ekonomik gücü, iklim ve coğrafik bakımdan karşılaşılan tabii sorunlar tane veriminde istenen düzeye ulaşılmasını kısıtlamaktadır (Yılmaz ve Akyürek, 1991; Kaydan ve Yağmur, 2007; Kaydan ve Yağmur, 2008; Kaydan ve ark., 2011).

\section{Van İli İklim ve Toprak Verileri}

\section{1. İklim verileri}

Doğu Anadolu Bölgesi iklimi karasal özelliklere sahiptir. Karasallık en sicak ve en soğuk aylar arasındaki yıllık farkın ifadesi olup, bu fark büyüdükçe karasallığın şiddeti de artar. Türkiye'nin kıy kesimlerinde genel olarak $20{ }^{\circ} \mathrm{C}$ civarında seyreden bu fark, doğu kesimlerinde artar. Söz gelimi, fark Hakkari'de $28.5{ }^{\circ} \mathrm{C}$ Muş'ta $32.5{ }^{\circ} \mathrm{C}$ ve Bitlis'te $26{ }^{\circ} \mathrm{C}$ iken Van Gölü çevresinde $25{ }^{\circ} \mathrm{C}$ 'dir (Anonim, 2015) . Farkın en yüksek olduğu Muş ile Van arasında bu yönüyle $7.5^{\circ} C^{\prime}$ lik bir fark bulunmaktadır. Çizelge 1'de 1938-2017 yılları arası Meteoroloji Genel Müdürlüğünce kaydedilen Van İli Uzun Yıllar İklim Verileri Ortalamaları verilmektedir. Buna göre Van İli Yıllık Ortalama Sicaklığının $9.4{ }^{\circ} \mathrm{C}$, En Yüksek Ortalama Sicaklığının $14.8^{\circ} \mathrm{C}$, En Düşük Ortalama Sicaklığının 3.6 ${ }^{\circ} \mathrm{C}$, Ortalama Güneşlenme Süresinin 94.1 saat, Ortalama Yağışlı Gün Sayısının 90.8 gün ve Aylık Toplam Yağış Miktarı Ortalamasının ise $3872 \mathrm{~mm}$ olduğu görülmektedir (Çizelge-1). İlde genel olarak tahıl ekilişinin yapıldığ Ekim ayı Uzun Yıllar Ortalama Sıcaklık değerinin $11.2{ }^{\circ} \mathrm{C}$, Ortalama Yağış Miktarının ise $46.8 \mathrm{~mm}$ olduğu anlaşılmaktadır. Güz buğday ekilişlerinin çıkış yaptığı mart ayı uzun yıllar ortalama sıcaklık değerinin $1.5^{\circ} \mathrm{C}$, ortalama yağışlı gün sayısının 11.9 gün aylık toplam yağış miktarı ortalamasının ise $46.7 \mathrm{~mm}$ olduğu görülmektedir. İlde Uzun Yıllar en yüksek ortalama sıcaklığın hasat ve harmanın yapıldığı Temmuz ayında olduğu $\left(22.2^{\circ} \mathrm{C}\right)$, en yüksek aylık yağış ortalamasının ise $(55.9 \mathrm{~mm})$ kardeşlenme ve sapa kalkma evrelerinin gerçekleştiği Nisan ayı içinde gerçekleştiği anlaşılmaktadır (Çizelge-1).

Çizelge 1.Van İli uzun yıllar ortalaması iklim verileri (Anonim 2018b)

VAN (mm) Ocak Şubat Mart Nisan Mayıs Haziran Temmuz Ağustos Eylül Ekim Kasım Aralık Yıllık

Ölçüm Periyodu ( 1938 - 2017)

\begin{tabular}{|c|c|c|c|c|c|c|c|c|c|c|c|c|c|}
\hline Ortalama Sicaklık $\left({ }^{\circ} \mathrm{C}\right)$ & -3.1 & -2.6 & 1.5 & 7.7 & 13.1 & 18.2 & 22.2 & 22.1 & 17.8 & 11.2 & 4.9 & -0.5 & 9.4 \\
\hline $\begin{array}{l}\text { Ortalama En Yüksek } \\
\text { Sicaklık }\left({ }^{\circ} \mathrm{C}\right)\end{array}$ & 1.8 & 2.5 & 6.4 & 12.7 & 18.4 & 23.8 & 28.1 & 28.4 & 24.2 & 17.3 & 10.2 & 4.3 & 14.8 \\
\hline $\begin{array}{l}\text { Ortalama En Düşük } \\
\text { Sicaklık }\left({ }^{\circ} \mathrm{C}\right)\end{array}$ & -7.6 & -7.2 & -2.9 & 2.5 & 6.9 & 10.7 & 14.5 & 14.5 & 10.6 & 5.6 & 0.3 & -4.6 & 3.6 \\
\hline $\begin{array}{l}\text { Ortalama Güneşlenme } \\
\text { Süresi (saat) }\end{array}$ & 4.5 & 5.3 & 6.0 & 7.2 & 9.3 & 11.7 & 12.1 & 11.4 & 9.8 & 7.0 & 5.5 & 4.3 & 94.1 \\
\hline $\begin{array}{l}\text { Ortalama Yağışlı Gün } \\
\text { Sayısı }\end{array}$ & 9.9 & 9.7 & 11.9 & 12.0 & 10.7 & 5.1 & 1.9 & 1.2 & 2.3 & 8.1 & 8.6 & 9.4 & 90.8 \\
\hline $\begin{array}{l}\text { Aylık Toplam Yağış } \\
\text { Miktarı Ortalaması }\end{array}$ & 34.6 & 33.6 & 46.7 & 55.9 & 45.8 & 18.1 & 5.4 & 3.7 & 13.6 & 46.8 & 47.0 & 36.0 & 387.2 \\
\hline
\end{tabular}

Buğday bilindiği gibi bir serin iklim tahılıdır ancak Dünyada birçok üretim bölgesinde başarı ile yetişir. Üretim 30-60 kuzey ve 27-40 güney paralelleri arasında yaygınlaşmıştır (Nuttonson, 1955). Minimum 3-4 ${ }^{\circ} \mathrm{C}$, optimum 25 ve maksimum $30-32{ }^{\circ} \mathrm{C}$ da yetişir (Briggle ve ark., 1980) . Yillık 
ortalama yağış1 $250 \mathrm{~mm}$. den $1750 \mathrm{~mm}$ 'ye kadar olan yerlerde yetişebilir. Ancak buğday yetişen alanların \% 75'inde yıllık yağış 375-875 mm arasındadır (Leonard ve Martin 1963).

\subsection{Toprak yapısı}

Ekmeklik buğday Dünyada çok çeşitli çevrelerde yetişen adaptasyon yeteneği en yüksek olan ve en geniş alanda yetiştirilen bir tahıl türüdür (Briggle ve Curtis, 1987). Bu yönüyle Van'da da kadimden beri buğday yetiştiriciliği yapılmaktadır. Buğday tarımı yapılan 26 ayrı noktada $0-20$ ve 20$40 \mathrm{~cm}$ derinliklerinden alınan 52 toprak örneğinin incelenmesinden elde edilen Van İli tarım topraklarının bazı fiziksel ve kimyasal özellikleri Çizelge 2'de, toprakların N, P, K, Cu, Fe, Mn ve Zn içerikleri ise Çizelge 3’te verilmektedir.

Çizelge 2. Van İli tarım topraklarının bazı fiziksel ve kimyasal özellikleri *

\begin{tabular}{lccccccccc}
\hline Toprak No & Derinlik & $\mathrm{pH}$ & $\begin{array}{c}\text { Kil } \\
\%\end{array}$ & $\begin{array}{c}\text { Silt } \\
\%\end{array}$ & $\begin{array}{c}\text { Kum } \\
\%\end{array}$ & $\begin{array}{c}\text { Kireç } \\
\%\end{array}$ & $\begin{array}{c}\text { Ca+Mg } \\
\text { Organic } \\
\%\end{array}$ & $\begin{array}{c}\text { KDK } \\
\text { me/100g }\end{array}$ \\
\hline Max & & 8.22 & 49.50 & 29.60 & 91.54 & 21.45 & 33.54 & 35.00 & 4.41 \\
Min & & 6.52 & 3.92 & 1.84 & 23.92 & 0.00 & 7.80 & 6.00 & 0.41 \\
Ort. (Av.) & $0-20$ & 7.69 & 27.31 & 18.54 & 54.15 & 7.69 & 21.79 & 23.94 & 2.18 \\
Ort. (Av.) & $20-40$ & 7.71 & 27.12 & 18.10 & 54.78 & 7.76 & 20.97 & 23.14 & 2.16 \\
Ort. (Av.) & & 7.70 & 27.22 & 18.32 & 54.46 & 7.73 & 21.38 & 23.54 \\
\hline
\end{tabular}

*Çimrin ve Boysan 2006'dan uyarlanmıştır.

Çizelge 2' ye göre Van İli tarım topraklarının pH içeriği 6.52-8.22 (ortalama 7.69), kil içeriği $\%$ 3.92-49.50 (ortalama \% 27.22), silt içeriği \% 1.84-29.60 (ortalama \% 18.32), kum içeriği \% 23.9291.54 (ortalama \% 54.46), kireç içeriği \% 0.00- 21.45 (ortalama \% 7.73), Ca+Mg düzeyleri 7.80-33.54 me/100 g (ortalama 21.38), KDK CEC içerikleri 6.00 -35.00 me/100 g (ortalama 23.54) ve organik madde miktarı \% 0.41-4.41 (ortalama \% 2.17) arasında değişmektedir. Çizelge 3'e göre, toprakların azot $(\mathrm{N})$ düzeylerinin \% 0.35-1.96, alınabilir fosfor $(\mathrm{P})$ düzeylerinin 3.3-20.0 ppm, değişebilir potasyum $(\mathrm{K})$ düzeylerinin 82-1314 ppm, alınabilir bakır $(\mathrm{Cu})$ düzeylerinin $0.32-4.60 \mathrm{ppm}$, demir (Fe) düzeylerinin 2.54-23.0 ppm, mangan $(\mathrm{Mn})$ düzeylerinin 1.80-14.70 ppm ve çinko ( $\mathrm{Zn}$ ) düzeylerinin 0.13-1.26 ppm arasında bulunduğu görülmektedir (Çizelge 3).

Çizelge 3. Van İli tarım topraklarının N, P, K, Cu, Fe, Mn ve Zn içerikleri *

\begin{tabular}{|c|c|c|c|c|c|c|c|c|}
\hline $\begin{array}{l}\text { Toprak } \\
\text { No: }\end{array}$ & Derinlik & $\begin{array}{l}\mathrm{N} \\
\%\end{array}$ & $\begin{array}{c}\mathrm{P} \\
\mathrm{ppm}\end{array}$ & $\begin{array}{c}\mathrm{K} \\
\mathrm{ppm}\end{array}$ & $\begin{array}{l}\mathrm{Cu} \\
\mathrm{ppm}\end{array}$ & $\begin{array}{c}\mathrm{Fe} \\
\mathrm{ppm}\end{array}$ & $\begin{array}{l}\text { Mn } \\
\text { ppm }\end{array}$ & $\begin{array}{l}\mathrm{Zn} \\
\mathrm{ppm}\end{array}$ \\
\hline Min & & 0.35 & 3.3 & 82 & 0.32 & 2.54 & 1.80 & 0.13 \\
\hline Max & & 1.96 & 20.0 & 1314 & 4.60 & 23.0 & 14.70 & 1.26 \\
\hline Ort. (Av.) & $0-20$ & 1.06 & 10.14 & 625.5 & 1.59 & 7.45 & 6.65 & 1.44 \\
\hline Ort. (Av.) & $20-40$ & 1.02 & 7.63 & 570.2 & 1.49 & 6.85 & 5.49 & 0.31 \\
\hline Ort. (Av.) & & 1.04 & 8.88 & 579.8 & 1.54 & 7.15 & 6.07 & 0.87 \\
\hline
\end{tabular}

*Çimrin ve Boysan 2006’dan uyarlanmıştır.

Azotça fakir toprakların $\% 11$, orta düzeydekilerin $\% 36.5$, iyi düzeydekilerin $\% 46.0$, zengin düzeydekilerin \% 6'lık kısmı oluşturduğu belirlenmiştir. Toprakların \%30.8'inde fosfor içeriğinin çok az, \%50.0'inde az, \%19.2' sinde fosforun orta düzeyde olduğu anlaşılmıştır. Tüm toprak örneklerinin değişebilir potasyum içerikleri bakımından yeter ve çok yüksek düzeyde oldukları sadece örnek alınan bir noktanın (Heybeli köyü) bunun dışında olduğu saptanmıştır. Fosfor ve alınabilir çinko açısından toprakların büyük bir kısmında yetersizlik görülürken, alınabilir bakır, demir ve mangan açısından herhangi bir noksanlık bulunmadığı anlaşılmıştır (Çimrin ve Boysan, 2006).

\section{Van İli Tarım Alanı ve Buğday Tarımının Türkiye ve Bölgedeki Yeri}

\subsection{Türkiye’deki yeri}

Türkiye ve Van İli genel arazi dağılım bilgileri çizelge 4' te verilmektedir. Buna göre Türkiye'deki 38.2 milyon ha' lık tarımsal arazi varlı̆̆ 
iken, Van İl'inde toplam arazi içindeki en büyük payı (\% 64.9) 1.35 milyon ha ile Çayır-Meralar oluşturmaktadır. Van'da tarım arazisi miktarının 371182 ha olduğu görülmektedir.

Çizelge 4. Türkiye ve Van İli genel arazi dağılımı (Anonim 2017)

\begin{tabular}{lcccc}
\hline \multicolumn{1}{c}{ Alan Adı } & Van & \multicolumn{2}{c}{ Türkiye } \\
\hline Tarım Arazisi & Ha & $\%$ & Ha & 48.9 \\
Çayır Mera & 371182 & 18.31 & 38328000 & 18.65 \\
Orman & 1315881 & 64.9 & 14616687 & 27.30 \\
Diğer Alan & 26293 & 1.29 & 21289783 & 5.26 \\
\hline TOPLAM & 313574 & 15.50 & 4123230 & 78357700 \\
\hline
\end{tabular}

Türkiye ve Van İli seçilmiş tarla bitkilerinin üretim durumu bilgileri çizelge 5'te verilmektedir. Buna göre 2016 yılında Türkiye'nin serin iklim tahılları ekilişi 10.6 milyon ha, üretimi ise 27.8 milyon tondur. Aynı yıl Van'da 8627 bin da tahıl ekilişine karşılık 1178 bin ton üretim elde edilmiştir. Türkiye'deki serin iklim tahılları ekilişinin \%72'sini buğday (7.6 milyon ha) oluşturmakta iken, bu oran Van'da \% 91 civarındadır. Türkiye'de buğday (20.6 milyon ton) toplam tahıl üretiminin \% 74.1'ini, Van'da ise 787314 da alanda ekiliş karşıllğında \% 88.6'sını (104 4 bin ton) oluşturmaktadır. Van'da bunun yanı sıra tarla tarımında kullanılan 2.13 milyon da alan içinde yem bitkileri yetiştiriciliği önemli bir yer tutmakta, yonca ve korunga ekilişleri 1.25 milyon da, üretimi ise 2.65 milyon tondur (Anonim, 2017). İlde endüstri bitkilerinden şekerpancarı ve patates üretimi ile yöresel fasulye çeşitlerinin yetiştiriciliği de yapılmaktadır.

Çizelge 5. Türkiye ve Van İli seçilmiş tarla bitkilerinin üretim durumu (Anonim 2017)

\begin{tabular}{|c|c|c|c|c|}
\hline \multirow[b]{2}{*}{ Ürün Ad1 } & \multicolumn{2}{|c|}{ Van } & \multicolumn{2}{|c|}{ Türkiye } \\
\hline & Ekiliş (Da) & Üretim (Ton) & Ekiliş (Da) & Üretim (Ton) \\
\hline Buğday & 787.314 & 104440 & 76719 448* & 20600000 \\
\hline Arpa & 75.401 & 13387 & $27400521^{* *}$ & 6700000 \\
\hline Çavdar & & & 1146493 & 300000 \\
\hline Yulaf & & & 994379 & 225000 \\
\hline Tahıl Toplam & 862715 & 117827 & 106260841 & 27825000 \\
\hline Yonca & 1024838 & 2222010 & 6501107 & 15714381 \\
\hline Korunga & 227418 & 430362 & 1936940 & 1982047 \\
\hline Yem Bitkileri Toplam & 1252256 & 2652372 & 8438047 & 17696428 \\
\hline Ş. Pancarı & 10013 & 40212 & 3224477 & 19465452 \\
\hline Patates & 2460 & 6652 & 1448572 & 4750000 \\
\hline Fasulye & 2245 & 2252 & 495639 & 638532 \\
\hline
\end{tabular}

\subsection{Van İli’nin TRB2 bölgesine göre tarımsal arazi varlı̆̆ı ve tahıl üretim durumu}

Van, Bitlis, Muş ve Hakkari' den oluşan TRB2 Bölgesi illeri arazilerinin kulanım biçimlerine göre dağılımı çizelge 6'da verilmiştir. Buna göre Bölge 4.49 milyon ha yüzölçümüne ve 9134 bin ha tarım arazisine sahiptir. Çayır mera alanları yüzölçümünün yarısından fazla bir orana tekabül ederken, tarım alanları \% 20.3' lük bir orana sahiptir. Bölgede tarım alanlarının Türkiye'nin tarım alanlarına (38.2 milyon ha) oranı \% 2.4 civarındadır. Van İli 3722 bin ha tarım arazisiyle Bölge'nin en geniş tarım alanına sahip olup, Bölge tarım alanları içindeki payı \% 40.7' dir. Van İli'nin çayır mera miktarının fazlalığı dikkat çeken başka bir husustur. İlin çayır mera miktarı (1.36 milyon ha) 
Bölge'nin bu varlığının \% 56.6'sını oluşturmaktadır. Bunun dışında Van'da 56301 ha tarım dışı arazi ve 98.138. ha nadas alanı bulunmaktadır.

Çizelge 6. TRB2* Bölgesinde Arazinin Kullanım Biçimlerine Göre Dağılımı (Anonim, 2014b).

\begin{tabular}{cccccc}
\hline & $\begin{array}{c}\text { Arazi Yüz } \\
\text { Ölçümü } \\
\text { (ha) }\end{array}$ & Tarım Alanı & $\begin{array}{c}\text { Çayır Mera } \\
\text { Alanı }\end{array}$ & $\begin{array}{c}\text { Ormanlık ve } \\
\text { Fundalık Alanı }\end{array}$ & Diğer Alan \\
\hline Bitlis & 858200 & 134918 & 297662 & 164756 & 260864 \\
Hakkari & 714684 & 61463 & 369635 & 174955 & 108632 \\
Muş & 819600 & 344842 & 373362 & 57147 & 44249 \\
Van & 2100300 & 372196 & 1359022 & 26294 & 342788 \\
TRB2 & 4492784 & 913419 & 2399681 & 423152 & 756533 \\
Türkiye & 78357700 & 38247000 & 14617000 & 21537000 & 3956700 \\
\hline
\end{tabular}

*TRB2: Kalkınma Bakanlığı Bölge Sistemi (Van, Hakkari, Muş ve Bitlis İlleri)

Türkiye'de tarımsal yapı ağırlıklı olarak özel mülkiyete dayalı küçük aile işletmelerinden oluşmaktadır. Türkiye'nin bu durumu $\mathrm{AB}$ ile kıyaslandığında işletme sayısı AB'de 13.7 milyon Türkiye'de 3 milyon, ortalama işletme büyüklüğü AB'de 15.8 ha, Türkiye'de 6 ha, parsel sayıs1 AB'de 11.24 milyon Türkiye'de 12.3 milyondur (Özgüven ve ark., 2010). 2001 yılında yapılan genel tarım sayımı sonuçları Türkiye de en büyük işletme büyüklüğünün 19485 da ile Şanlıurfa'da, en düşük işletme büyüklüğünün ise 11.51 da ile Rize'de bulunduğunu göstermiştir. Tarım işletmeleri çok parçalı ve küçük ölçekli olduğunda, yeni teknoloji kullanımı sınırlandığından tarımsal faaliyetlerden elde edilen üretim azalmakta ve birim alandan elde edilen karlılık ta böylece düşmektedir (Özgüven ve ark., 2010). TRB2 Bölgesi illerinin arazi ölçeklerine ait işletme sayıları çizelge 7'de görülmektedir. Bu dağılıma göre Bölge 157.838 adet işletmeye sahiptir. Bu işletmelerin yarısı civarındaki kısmı (81.804 adet) işletme Van'da bulunmaktadır. Bölgede 10-20 da ölçeği arası büyüklüğe sahip işletme sayısı 40 821 adetle diğer ölçekler içinde en fazla mevcuda olup, yine bunun yarısından fazlası (22.249) Van'da yer almaktadır. Bölgede 1000-2500 da arası büyük ölçekli araziye sahip işletme mevcudunun (7 adet) azlığı ve bunların yarısından fazlasının (4 adet) Van'da bulunması dikkat çekmektedir. Bölgenin 500 da ve üzeri araziye sahip işletme sayısı 16 olup, bunların 7'si Van'da bulunmaktadır. Tarım arazileri miktarı işletme sayılarına oranlandığında, işletme başına Bölge'de 5.78 ha, Van'da 4.54 ha tarım arazisinin düş̧üğü görülmektedir. Türkiye'de ise bu miktar 7.80 ha civarındadır (Anonim, 2016).

Çizelge 7. TRB2 Bölgesi arazi ölçeklerine göre işletme sayısı (Anonim, 2014b).

\begin{tabular}{cccccc}
\hline Arazi Dilimleri (da) & Hakkari & Bitlis & Muş & Van & TRB2 \\
\hline $5>$ & 36 & 3645 & 9322 & 19991 & 32994 \\
$5-10$ & 295 & 3527 & 11114 & 20217 & 35153 \\
$10-20$ & 1839 & 3848 & 12885 & 22249 & 40821 \\
$20-50$ & 4108 & 4350 & 11004 & 16480 & 35942 \\
$50-100$ & 1802 & 2557 & 3295 & 4125 & 11779 \\
$100-200$ & 438 & 892 & 700 & 582 & 2612 \\
$200-500$ & 89 & 110 & 169 & 460 & 3 \\
$500-1000$ & 0 & 4 & 2 & 4 & 9 \\
$1000-2500$ & 0 & 2 & 48492 & 81804 & 157838 \\
\hline Toplam & 8607 & 18935 & & 3 & 9 \\
\hline
\end{tabular}

Tarım faaliyetlerde makinaların kullanılmasıyla faaliyetin verimliliği dolaylı olarak artmakta, kırsal alanda yeni üretim modellerinin uygulanmasını teşvik etmektedir. Makine kullanımı aynı zamanda tarımda işçiliği azaltmakta, çalışma koşullarının konforunu iyileştirmekte ve faaliyetin karlılığının artmasına öncülük etmektedir. Alana göre ihtiyaç duyulan makinenin kullanımı, ölçeğe 
göre verim artışı ve karlılığın artması mümkün olmaktadır (Saral ve ark., 2000). 1000 ha alana düşen traktör sayısı Türkiye'de 38, AB'de 89, traktör sayısı Türkiye'de 1 milyon, AB'de 15 milyon, traktör başına düşen arazi miktarı Türkiye'de 26, AB'de 11.3 ha'dır (Özgüven ve ark., 2010).

TRB2 Bölgesi illerinin tarımsal alet ve makina varlığ 1 çizelge 8'de yer almaktadır. Çizelgeye göre Türkiye'nin 4346753 alet ve makine varlı̆ğna sahiptir ve bunun 43 241'i Bölge'de bulunmaktadır. Bölge'de alet makina mevcudu yönünden Muş ili' nin önde olduğu görülmekte, Van İli 12686 adet mevcuduyla Türkiye'nin \% 2.9' una, Bölge'nin ise \%29.3'üne denk bir varlığa sahiptir.

Van 5110 adet traktörle Türkiye'de \% 0.4, Bölge'de \% 30'luk paya sahipken, Muş İli traktör mevcuduyla Bölge'de en büyük paya sahiptir (Çizelge 8).

Traktör mevcutları arazi varlıklarına oranlandığında, 1 traktöre Türkiye'de 31.5 ha, Bölge'de 53.7 ha, Van’da ise 72.83 ha tarım arazisi düşmektedir.

Çizelge 8. TRB2 Bölgesi tarımsal alet ve makine varlığı (Anonim, 2014b).

\begin{tabular}{lcccccc}
\hline & Bitlis & Hakkari & Muş & Van & TRB2 & Türkiye \\
\hline Traktör & 2000 & 689 & 9203 & 5110 & 17002 & 1213560 \\
Biçerdöver & 2 & 0 & 0 & 3 & 5 & 15486 \\
Diğer Alet ve Makineler & 4163 & 2032 & 12466 & 7573 & 26234 & 3117707 \\
\hline Toplam & 6165 & 2721 & 21669 & 12686 & 43241 & 4346753 \\
\hline
\end{tabular}

TRB2 Bölgesi buğday ekiliş ve üretimine dair bilgiler çizelge 9'da verilmektedir. Bunlara göre Türkiye'nin durum buğdayı dışındaki ekiliş alanı 64.9 milyon da, üretimi 17.9 milyon ton ve verimi $278 \mathrm{~kg} / \mathrm{da}$ 'dır. Buna mukabil TRB2 Bölgesi'nin 2.48 milyon da ekiliş alanı, 3792 bin ton üretimi ve $156 \mathrm{~kg} / \mathrm{da}$ verimi bulunmaktadır. Van İli’nin ekiliş alanı 8627 bin da, üretimi 1156 bin ton ve verimi ise $144 \mathrm{~kg} / \mathrm{da}$ 'dır. Van İli ekiliş alanı Türkiye'nin \%1.3 ve Bölge'nin \% 34'üne, üretim miktarı Türkiye'nin \% 0.6 ve Bölge'nin \% 30.4'üne tekabül etmektedir. İl'in ve Bölge'nin verimi ise Türkiye'nin yarısına yakın bir seviyede seyretmektedir. Çizelge'de Muş İli ekiliş ve üretiminin Bölge'de en yüksek seviyede olduğu dikkati çekmektedir.

Çizelge 9. TRB2 Bölgesi buğday ekilen alan ve üretim miktarı (Anonim, 2014b)

\begin{tabular}{cccc}
\hline 2013 & Ekilen Alan (Da) & $\begin{array}{c}\text { Üretim Miktar1 } \\
(\text { Ton })\end{array}$ & Verim (Kg/Da) \\
\hline Türkiye & $64940000^{*}$ & $17975000^{*}$ & 278 \\
TRB2 & 2482299 & 379163 & 156 \\
Bitlis İl Toplam & 366238 & 53260 & 153 \\
Hakkari İl Toplam & 84971 & 10697 & 136 \\
Muș İl Toplam & 1168378 & 199655 & 176 \\
Van İl Toplam & 862712 & 115551 & 144 \\
\hline
\end{tabular}

*Durum buğdayı hariç

\section{4. İlgili Kurum ve Kuruluşların İlde Buğday Konusundaki Faaliyetleri}

\subsection{Tarım kredi kooperatiflerinin faaliyetleri}

Van'da buğday ekilen 787324 da alan için $20 \mathrm{~kg} / \mathrm{da}$ tohumluk ihtiyacı (Anonim, 2018) dikkate alındığında 15740 ton tohumluk ihtiyacı bulunmaktadır. Bu ihtiyacın büyük bir kısmı çiftçinin kendi yerel çeşit tohumluğu kullanılarak karşılanırken, bir kısmı özel tohumluk şirketlerinden diğer bir kısmı kamu kurum ve kuruluşlarının tedarikleri yoluyla karşılanmaktadır.15 740 ton tohumluk kullanımına karşılık 104440 ton verim elde edilmesi (Anonim, 2017) yapılan tarımsal faaliyetten yeterince ürün elde edilemediğini ortaya koymaktadır. $\mathrm{Bu}$ durum verim düşüklüğünden kaynaklanmaktadır.

Tarımsal faaliyetler için tohumluk girdisi temin eden kurum ve kuruluşlardan, Tarım Kredi Kooperatifleri Genel Müdürlüğünce Van İli çiftçileri için temin edilen buğday tohumluk bilgileri 
çizelge 10’da verilmektedir. Çizelge 10’a göre 2010-2018 yılları arasında Van İli için temin edilen tohumluk miktarı 29877 tondur. Kuruluş tarafından Van İli için 84 çiftçiye 5 tohumluk buğday çeşidi temin edilmiştir. Bunlardan Bezostaja-1 çeşidi 54 çiftçi için 198.87 ton, Ceyhan-99 çeşidi 3 çiftçi için 17 ton, Pehlivan çeşidi 6 çiftçi için 25.05 ton, Krasunia Odeska çeşidi 7 çiftçi için 35.95 ton ve Renan çeşidi 14 çiftçi için 21.9 ton temin edilmiştir. Tohumluklar içinde en fazla talep edilen Bezostaja-1 çeşidi olmuştur.

Çizelge 10. Tarım Kredi Kooperatifleri Van İli tohumluk tedarik bilgileri (Anonim, 2018c)

\begin{tabular}{|c|c|c|c|c|}
\hline$\overline{Y 1}$ & İlçe & Çeşit & Çiftçi sayısı & Miktar (kg) \\
\hline \multirow[t]{3}{*}{2010} & Merkez & Bezostaja-1 & 15 & 50000 \\
\hline & & Bezostaja-1 & 16 & 52500 \\
\hline & & Ceyhan-99 & 3 & 17000 \\
\hline \multirow[t]{5}{*}{2011} & Erciş & Pehlivan & 5 & \\
\hline & & & & 25000 \\
\hline & & Krasunia Odeska & 4 & \\
\hline & & & & 15500 \\
\hline & Erciş Toplam & & 28 & 110000 \\
\hline \multirow[t]{2}{*}{2012} & Edremit & Bezostaja-1 & 1 & 6925 \\
\hline & & Bezostaja-1 & 6 & 19950 \\
\hline \multirow[t]{3}{*}{2012} & Erciş & Pehlivan & 1 & 50 \\
\hline & & Krasunia Odeska & 3 & 20450 \\
\hline & Erciş Toplam & & 10 & 40450 \\
\hline 2013 & Merkez & Bezostaja-1 & 7 & 44000 \\
\hline 2013 & Erciş & Bezostaja-1 & 4 & 9500 \\
\hline 2015 & Erciş & Bezostaja-1 & 2 & 15100 \\
\hline 2016 & Gevaş & Bezostaja-1 & 1 & 650 \\
\hline 2017 & Van & Bezostaja-1 & 2 & 250 \\
\hline 2017 & Erciş & Renan & 12 & 20200 \\
\hline 2018 & Erciş & Renan & 2 & 1700 \\
\hline Genel Toplam & & 5 & 84 & 298775 \\
\hline
\end{tabular}

Çizelge 10'a göre en fazla tohumluk tedariki Erciş ilçesi için yapılmış ve bu 2012 yılında 110 ton olarak gerçekleşmiştir. Tohumluk kullanan 34 çiftçiyle yapılan görüşmelerde Bezostaja-1 çeşidinden ortalama $380 \mathrm{~kg} / \mathrm{da}$, Renan çeşidinden ortalama $263 \mathrm{~kg} / \mathrm{da}$ verim alındığ 1 belirtilmiştir. Diğer çeşitler hakkında yapılan çiftçi görüşmelerinden sağlıklı veri alınamamıştır (Anonim, 2018d).

\subsection{Toprak mahsulleri ofisinin faaliyetleri}

Toprak Mahsulleri Ofisi Genel Müdürlüğünce Van İlinde üretilen 2010 y1lında 746 ton, 2014 yılında 4895 ton ve 2015 y1lında 8.892 ton olmak üzere toplam 14533 ton buğday alımı gerçekleştirilmiştir (Anonim, 2018e). Van'da üretilen buğdayın kalite özelliklerinden kaynaklanan nedenlerle alım miktarları düşük tutulmaktadır.

\subsection{Un sanayiinin durumu}

Van' da bulunan 10 adet un fabrikasında yilda 112 bin ton un üretilmektedir (Anonim, 2017). Bunun için kullanılan hammaddenin 26 bin tonu Van'da üretilen buğdaydan, 86000 tonu ise Van dışında üretilen buğdaydan temin edilmektedir. Van un sanayii tarafından un üretiminde ağırlıklı olarak Van dışı buğdayların tercih edilmesinin nedeni, Van buğdaylarının protein, sedim ve gluten değerlerinin düşüklügü şeklinde belirtilmiştir. Buğday tedariki ağırlıklı olarak Muş ve Diyarbakır illerinden yapılmakta gluten, protein değerleri ve un randımanları yüksek olduğundan Ceyhan-99, 
Bezostaja-1, Adana Pandas ve Sekreterya (Sagittario) çeşitleri tercih edilmektedir. Van buğdaylarından elde edilen un daha çok tandırlık ve bisküvi sanayiinde kullanılmaktadır (Anonim, 2018f).

\subsection{Tarım Bakanlığı'nın desteklemeleri}

Gıda Tarım ve Hayvancılık Bakanlığı tarafindan tarımsal faaliyetler karşılığında birtakım destek ve teşvikler verilmektedir. Bakanlık tarafından buğday ekili alanlar için 2017 yılında 17934 635,86 TL MGD desteği, 972 424,57 TL hububat fark ödemesi ve 3590 918,15 TL organik tarım (buğday) desteği, 2018 y1lında ise 18731 062,03 TL MGD desteği, 219 465,52 TL hububat fark ödemesi ve 182 920,06 TL hububat fark ödemesi verilmiştir. Bunun dışında 2018 yılında buğday ve arpada yurtiçi sertifikalı tohum kullanım desteği $8.5 \mathrm{TL} /$ da olarak tespit edilmiştir. Bir dekara $20 \mathrm{~kg}$ tohumluk kullanımı hesabıyla $0.425 \mathrm{TL} / \mathrm{kg}$ tohum kullanım desteği sağlandığı anlaşılmaktadır (Anonim, 2018g).

\section{Van'da yetiştiriciliği denenen bazı buğday çeşitleri}

Van'da gerek bilimsel araştırmalar gerekse üretim amacıyla birçok tescilli buğday çeşidinin yetiştiriciliği yapılmıştır. Yetiştiriciliği yapılan bu çeşitlerden çoğunlukla tatminkar verim elde edilmektedir.

2006-2009 yetiştirme sezonlarında Tir buğdayında (Triticum aestivum L.ssp vulgare Vill. v. leucospermum Körn) ekim yöntemleri ve ekim sıklıklarının buğdayda tane verimi, bazı verim öğeleri ve yabancı otlar üzerine etkilerini belirlemek amacıyla yürütülen bir araştırmada, tane verimleri en az 133.6kg/da (450 tohum $\left./ \mathrm{m}^{2}\right)$, en çok $171.8 \mathrm{~kg} / \mathrm{da}\left(650\right.$ tohum $\left./ \mathrm{m}^{2}\right)$ belirlenmiştir (Kaydan ve ark., 2011).

2005-06 ve 2006-07 yetiştirme sezonlarında Van'da 1 yerel ve 15 tescilli ekmeklik buğday (Tiriticum aestivum L.) çeşitlerinin verim ve verim öğelerini belirlemek için yürütülen bir araştırmada tane verimi 167.07 - $238.36 \mathrm{~kg} / \mathrm{da}$ arasında gerçekleşmiştir. Bunlardan Doğu-88 çeşidinden 238.36 $\mathrm{kg} / \mathrm{da}$, Nenehatun çeşidinden $233.50 \mathrm{~kg} / \mathrm{da}$, Alparslan çeşidinden $220.75 \mathrm{~kg} / \mathrm{da}$, Lancer çeşidinden 217.25 kg/da, Harmankaya çeşidinden 207.00 kg/da, Bezostaja-1 çeşidinden 185.98 kg/da ve yerel Tir çeşidinden $167.07 \mathrm{~kg} / \mathrm{da}$ verim alınmıştır (Kaydan ve Yağmur, 2008).

1994-1995 yıllarında iki yıl boyunca Van'da Tir buğdayında tane verimi ve bazı verim öğeleri arasındaki ilişkileri belirlemek amacıyla yürütülen bir araştırmada 90 yerel tir hattının tane verimleri $339.47-471.30 \mathrm{~kg} / \mathrm{da}$ arasında belirlenmiştir (Sönmez ve ark., 1999).

2004-2006 yılları arasında Van'da 1 Tir yerel hattı ve 9 tescilli buğday çeşidi kullanılarak farklı ekim derinliklerinin verim ve verim unsurları üzerine etkilerini incelemek üzere yürütülen bir araştırmada en yüksek tane verimi $5 \mathrm{~cm}$ ekim derinliğinde Alparslan çeşidinde $298 \mathrm{~kg} / \mathrm{da}$ olarak tespit edilmiştir. Bunun dışında aynı ekim derinliğinde Doğu- 88 çeşidinden $273 \mathrm{~kg} / \mathrm{da}$, Tir hattından 272 $\mathrm{kg} / \mathrm{da}$, Nenehatun çeşidinden $265 \mathrm{~kg} / \mathrm{da}$, Kutluk-94 çeşidinden $255 \mathrm{~kg} / \mathrm{da}$, Süzen-97 çeşidinden 239 kg/da, Aytin-9 çeşidinden $237 \mathrm{~kg} / \mathrm{da}$, Altay-2000 çeşidinden $230 \mathrm{~kg} / \mathrm{da}$, Bezostaja-1 çeşidinden 228 kg/da ve Harmankaya-99 çeşidinden 211 kg/da verim alınmıştır (Yağmur ve Kaydan, 2009).

1991 yılında 1 Tir hattının (Triticum aestivum Sap.) sıraya, serpme ve tir ekim yöntemleriyle ekiminin verim ve verim unsurlarına etkilerinin incelendiği bir araştırmada sırasıyla tir, sıraya ve serpme ekim yöntemlerinde olmak üzere bitki boyları: 72.28-65.50-56.84 cm, metrekarede bitki say1s1: 242.08, 386.67, 368.92 adet $/ \mathrm{m} 2$, tane verimi: 143.97, 129.51, $105.11 \mathrm{~kg} / \mathrm{da}$ elde edilmiştir (Y1lmaz ve Akyürek, 1991).

\section{Sorunlar ve çözüm önerileri}

Buğday tarımının nihai amaçlarından birisi, un sanayinin ihtiyaç duyduğu nitelik ve kalitede buğday üretimi yapmaktır. Ancak Van İlinde buğday tarımının daha çok yerel çeşitlere dayalı olarak yapılması nedeniyle bu sektörün aradığı kalitede üretim yapılamamaktadır. Bunun dışında buğday tarımının önünde farklı problemler bulunmaktadır. Ancak bu problemlerin çözümü yine kendi içinde alınacak birtakım tedbirler ve uygulanacak bazı yöntemlerle mümkündür. 


\subsection{Sorunlar}

Van’da buğday üretimi konusunda yaşanan sorunlara, konu hakkında yapılan birtakım bilimsel çalışmalar, ilde gerçekleştirilen sektör değerlendirmeleri ve bu konu hakkında oluşturulan raporlarda değinilmiştir.

Konu hakkında hazırlanan bir raporda Van İlinde üretimi yapılan buğday, arpa gibi tahılların ekim alanı fazla olsa da, verimi düşük olduğundan gerçekleşen üretimin de düşük olduğu, bu nedenle bu sektöre dayalı sanayi tesislerin ihtiyaç duydukları hammaddeyi büyük oranda Van dışından temin ettiği, her ne kadar tahıl üretiminden yeterli verim alınamazsa dahi, buğdaya duyulan ihtiyacın bunun ilde yetiştiriciliğinin yapılmasını zorunlu kıldığı, bu nedenle özellikle bunun için elverişli olan tarım alanlarının Çaldıran'da \%40 (101 000 da) Özalp’te \%50 (154 500 da), Saray'da ise \%25’inin (19 743 da) tahıl yetiştiriciliğine ayrılması gerektiği (Anonim, 2014c) ifade edilmiştir. Diğer taraftan İl'de buğday yetiştiriciliğinde yaşanan problemler bazı bilimsel çalışmalarda da ifade edilmiştir. İl'de güz ekim döneminde Van Gölü havzası toprakları volkanik yapılı olduğundan, sonbaharda 4-6 cm derine yapılan serpme veya sıralı ekim sonrası alınan yağışlar nedeniyle oluşan sert kaymak tabakasının sebep oluğu \% 50 çıkış kayıplarının önüne geçmek için bu ekim yöntemleri yerine tir ekim yöntemi tercih edilebilmektedir. Tir ekim yönteminde tohumlar ark içine derin bir tarzda ekilmektedir. Tir ekim yönteminde ekimler toprağın nemli kısmı olan karıklar içine 15-18 cm derinliğine (tohumlar 4-6 cm derinlikte kalacak şekilde) ekim yapıldığından çıkışlar sonbahar yağışlarından önce gerçekleşmekte böylece yă̆ışlardan sonra oluşan kaymak tabakasıyla çıkış kayıpları sorunu engellenmektedir. Ayrıca serpme ekimde $22-24 \mathrm{~kg} / \mathrm{da}$ tohum kullanılırken tir ekim yönteminde 8-10 kg/da tohum kullanılmaktadır. Serpme ekimle tir ekim yöntemi arasında $12-14 \mathrm{~kg} / \mathrm{da}$ civarında bir tohum fark1 bulunmaktadır.1970'lerden sonra Toprak ve Su İşleri Bölge Müdürlüğü çiftçilerin kullanması için ekim mibzeri imal etmiştir (Yılmaz ve Akyürek, 1991). Van'da buğday yetiştiriciliğinde verim ve kalitenin düşük olması (Anonim, 2011a; Anonim, 2011b), kaliteli sertifikalı tohumluk kullanımının yaygın olmaması, bazı hastalık ve zararlılarla mücadelede yetersiz kalınması, bazı ilçelerde buğday yetiştirilen alanların erozyona maruz olması, yanlış ekim teknik ve yöntemleri, mekanizasyon yetersizliği (Anonim, 2011a), arazilerin topoğrafik kısitlamaları ve ölçek nedeniyle mekanizasyona uygun olmayışı, sulu koşullarda yetiştiriciliğinin yapılmaması, arazilerin çok parçalı ve küçük ölçeğe sahip olması, geniş nadas alanları (98 000 ha), münavebe sisteminin uygulanmaması, yetersiz, bilinçsiz ve doğru analize dayanmayan gübre kullanımı, yöresel çeşitlerin verimlerinin ve un randımanlarının düşük olması, tahıl işleme teknolojilerinin tek yönlü ve yetersiz olması, çiftçinin çeşit ve yetiştiricilik konusunda bilgi yetersizliği, elverişsiz iklim ve toprak özellikleri (Kaydan ve Yağmur, 2008; Anonim, 2011a; Anonim, 2016), alanda çiftçi örgütlülügünün yetersiz ve etkisiz oluşu, üretim girdi maliyetlerinin yüksekliği, pazarlama problemleri, alanda yapılan bilimsel araştırmaların yetersizliği, gibi sorunlar yaşanmaktadır (Anonim, 2016).

\section{2. Çözüm önerileri}

İl'de buğday tarımına 737.314 da alan ayrılmakta, buradan 1044 bin ton üretim ve 1326 $\mathrm{kg} / \mathrm{da}$ verim elde edilmektedir. Diğer taraftan İl'de un fabrikalarının işlediği un miktarı 112 bin tondur (Anonim, 2017). Bu yönüyle üretimin ihtiyacı karşıladığını söylemek mümkün olabilir. Ancak kalite problemleri nedeniyle un sanayii Van'da üretilen buğdayın \% 20'sini kullanmakta geriye kalan ihtiyacı il dışından temin etmektedir (Anonim, 2018f). Bu durumda amaç ilde un sanayinin ihtiyaç duyduğu kalite standartlarına sahip buğday üretimini gerçekleştirmek olmalıdır. Diğer taraftan Van'da buğday yetiştiriciliğinden elde edilen verim Türkiye ortalamasının $(280 \mathrm{~kg} / \mathrm{da})$ oldukça altında olduğundan, verimin Türkiye ortalaması seviyesine çıkarılabilmesi halinde aynı üretimin mevcut ekiliş alanının yarısından (350-400 bin da) elde edilmesi ve arta kalan alanın diğer tahıl veya ürün yetiştiriciliğine ayrılası mümkün olabilecektir. Bunu gerçekleştirmenin yolu, İl'de kullanımı yaygın olan verimi ve kalitesi düşük çeşitlerin yerine yüksek verimli ve kaliteli çeşitlerin kullanılması ve yaygınlaştırılması olacaktır. Dönemsel tohumluk ihtiyacının karşılanması için sürekli olarak çeşit tescil çalışmalarına ihtiyaç duyulması nedeniyle (Anonim, 2018a), bunun için gerekli araştırma çalışmalarının devamlı ve güncel çeşitlerle yapılması gerekmektedir. Bu yönüyle İl'de ihtiyaca yönelik yeterli düzeyde bilimsel çalışmanın yapılmadığı görülmektedir. Bu nedenle bilimsel araştırma konularının alanın ihtiyaçlarına göre belirlenmesi ve yapılan bilimsel çalışma sonuçlarının üreticilerle 
paylaşılması, çiftçilere buğday yetiştiriciliği konusunda ciddi referans sağlayacaktır. Türkiye'de her yıl tescil edilen yeni çeşitlerle beraber çeşit tercihi konusunda oluşan kafa karışıklığını (İpekçioğlu ve ark., 2014) gidermek için, İl'de yöresel hatların verimli çeşitlerle sslahı yapılarak adaptasyon kabiliyeti yüksek, hastalık ve zararlılara dayanıklı, un randımanı ve kalitesi yüksek verimli çeşitlerin geliştirilmesine ihtiyaç bulunmaktadır (Anonim, 2017). Buğday yetiştiriciliği konusunda çiftçilerin bilgi, teknik, materyal ve mekanizasyon eksikliğinin giderilmesi için; etkin, sürekli ve yaygın çiftçi eğitimi sağlanmalı, yeni çeşitler konusunda çiftçilere düzenli bilgi aktarılmalı, geleneksel tarım yöntemleri yerine tescilli materyal, modern teknik, ve mekanizasyon kullanımı örnek çalışmalarla özendirilmeli, tüm işletmelerin yararlanabileceği ortak makine parkları oluşturulmalıdır (Anonim, 2011). İldeki traktör açığı ve mekanizasyon ihtiyacının (Anonim, 2014) yetkili kurumlar tarafından daha önce alet ekipmana verilen destek benzeri sübvanse edilerek giderilmesi mümkündür. Ayrıca bu alanda işletmelerin ihtiyaç duyduğu uzman desteğinin, tarımsal danışmanlık sisteminin devlet eliyle yeniden yeterli düzeyde teşvik edilmesi çiftçilerin teknik bilgi yetersizliğinin giderilmesine ciddi katkı sağlayacaktır. Alanda yetersiz ve etkisiz örgütlenme açığının giderilmesi için, etkin çiftçi örgütlenmesi temin edilmeli, aynı alandaki aktörlerin (tedarikçi, üretici, sanayici, üniversite, kamu, meslek odası v.b.) eşgüdümü sağlanmalıdır. Böylece sektörde oluşturulacak bu örgütlü yapı eliyle uygun şekilde tedarik edilerek yüksek girdi maliyetlerinin tesirlerinden kurtulmak ve olası pazarlama problemlerini çözmek mümkün olacaktır. Buna ilave olarak hububat kalite kontrol merkezi kurulması, tek yönlü tahıl işleme tesislerinin çeşitlendirilmesi özellikle yöresel çeşitlerin bisküvi gibi farklı maksatlarla değerlendirilebilmesinin önünü açacaktır. Geçmişten günümüze biyolojik bir miras olarak ulaşan geleneksel bilgi ve arazi kullanım uygulamalarına ve yeni buğday çeşitleriyle rekabet edemediğinden kaybolmaya yüz tutmuş yerel buğday çeşitleri ve bunların ataları muhafaza altına alınmalıdır (Özberk ve ark., 2016). Yöresel buğday hatlarının bisküvi, tandırlık un gibi alternatif alanlarda da değerlendirilmesi yoluna gidilerek sürekli üretimi ve dolaylı olarak korunması sağlanmış olacaktır (Anonim, 2016). İklim ve toprağın dezavantajlı durumu ise organik üretimin öne çıkarılmasıyla avantaja çevrilmesi mümkündür (Anonim, 2011a). İl'de hakim olan çok parçalı ve küçük işletme yapısıyla büyük alanlarda mekanizasyon kullanarak buğday yetiştiriciliği ekonomik bir faaliyet değildir. Küçük işletme ölçeği ve çok parçalı arazi yapısından kaynaklanan sorunları toplulaştırma yoluyla gidermek gerekmektedir. İl'de ayrıca her yıl 100 bin da civarında bir alan nadasa bırakılmaktadır (Anonim, 2017). Bu şekilde üretimin dışına çıkarak atıl pozisyonda bekleyen bir alanın münavebe sistemlerine dahil edilerek değerlendirilmesi (Anonim, 2011b; Anonim, 2016) mümkün olacaktır. Münavebe uygulaması ile hem nadas alanlarının etkin kullanımı sağlanabilecek hem de münavebeye giren bitkiler yoluyla toprakta bitki besin maddesi birikmesi sağlanabilecektir. $\mathrm{Bu}$ yolla ardından yetiştirilen buğdayın verim ve kalitesinde artış sağlanacaktır. Diğer taraftan Milli Emlak Genel Müdürlüğü tarafından 4706 sayılı Kanunun Ek-6'ncı maddesi ve 387 sıra sayılı Millî Emlak Genel Tebliği çerçevesinde "Hazine Arazilerinin Tarımsal Amaçlı Kiralanması" uygulaması çerçevesinde düşük bedelle ve uzun süreyle hazine arazilerinin buğday üretiminde kullanılabilmesi mümkün (Anonim, 2018f) olacaktır. Özel sektör veya çiftçilerin büyük alanda buğday yetiştiriciliği için bu yöntemden faydalanması İl'de ihtiyaç duyulan verimli çeşitlerin, mekanizasyon kullanılarak üretilmesi yoluyla yöredeki buğday yetiştiricilerine ciddi bir örnek teşkil edebilir.

\section{Sonuç}

Van'da yem bitkilerinden sonra en geniş üretim alanı buğday tarımına ayrılmaktadır. Bu kadar geniş bir alanda yetiştiriciliği yapılan buğdayda birim alandan alınan verim Türkiye ortalamasının yarısı civarında olduğu için ekiliş alanına uygun üretim yapılamamaktadır. İl'de buğday işleyen sanayinin de ihtiyaç duyduğu kalitede üretim yapılamadığı için ihtiyaç duyulan hammaddenin \% 80'i İl dışından temin edilmektedir. İl'de buğday yetiştiriciliğinin öncelikli sorunu, verim ve kalitesi yüksek çeşitler yerine genel olarak yöresel çeşitlerin yetiştirilmesidir. Yöresel çeşitler biyolojik ve genetik bir değeri ifade ettiği için korunmaları gerekmekle beraber bu kadar geniş alanda yetiştirilmeleri kalite ve verim düşüklüğünün aynı zamanda nedenidir. Buğday yetiştiriciliğinde bunun dışında küçük ölçekli ve çok parçalı araziden oluşan işletme yapısı, arazilerin mekanizasyona uygun olmayışı, traktör ve diğer gerekli ekipmanın yetersizliği gibi başlıca sorunlar Van'da buğday yetiştiriciliğinin önünde engel teşkil etmektedir. Bu sorunların çözümü ise, kendi içinde yapılacak bazı düzenlemeler ve yöntem değişiklikleri ile mümkün olabilecektir. Tarım Bakanlığ tarafından sertifikalı 
tohum kullanımı için verilen desteklerin arttırılması bölgede buğday üretiminde kaliteli tohumluk kullanımını önemli ölçüde arttıracaktır. Böylece hem birim alandan daha yüksek verim elde edilebilecek hem de un sanayinin ihtiyaç duyduğu kalitede buğday üretimi gerçekleştirilebilecektir. Diğer taraftan mibzer kullanımı ve traktörle işlenen birim arazi yönünden Türkiye ortalamasının gerisinde bulunan bölgenin bu ihtiyacı yine Tarım Bakanlığı'nın daha önce olduğu gibi yeniden alet ekipman desteği sağlaması yoluyla giderilebilecektir.

\section{Kaynakça}

Anonim, (2011a). 2023 Dünya Şehri Van Tarım ve Gıda Çalışma Grubu Ön Çalışma Raporu, Van İl Tarım Müdürlüğü Yayınları, Van. 137.

Anonim, (2011b). Arama Konferansı Sonuç Raporu. Van İl Tarım Müdürlüğü, 2023 Dünya Şehri Van Vizyonu Tarım ve Gıda Çalışma Grubu Arama Konferansı, 23-24 Mart 2011, Van. 46.

Anonim, (2014a). Food and Agriculture Organization of the United States (FAO). World Total Cereal Production. http://www.fao.org/faostat/en/\#data/QC. (Erișim tarihi: 10 Eylül, 2017).

Anonim, (2014b). Doğu Anadolu Kalkınma Ajansı TRB2 Bölgesi Tarım Mevcut Durum Analizi, http://www.daka.org.tr/panel/files/files/TRB2BölgesiMevcutDurumAnalizi.pdf. (Erişim tarihi: 23 Kasim, 2018).

Anonim, (2014c). Van Vizyon 2023 Ortak Akıl Stratejik Eylem Planı. Doğu Anadolu Kalkınma Ajans1.http://www.daka.org.tr/panel/files/files/yayinlar/vizyon_2023_van_eylem.pdf. (Erişim tarihi: 23. Kasım, 2018)

Anonim, (2015). Van İli Tarım Sektörü Yatırım Klavuzu. Van GTHM, DAKA http://www.daka.org.tr/panel/files/files/yayinlar/VanİliTarımSektörüYatırımKlavuzu.pdf. (Erișim tarihi: 23 Kasım, 2018)

Anonim, (2016). 2015 Yılı Faaliyet Raporu. Van İl Gıda Tarım ve Hayvancilık Müd.Yay., Van. 1,217. Anonim, (2017). 2016 Yll Faaliyet Raporu, Van Gida Tarım ve Hayvancılık Müd. Yay., Van. 540 s.

Anonim, (2018a). Toprak Mahsulleri Ofisi Genel Müdürlüğü (TMO). 2017 Faaliyet Raporu. http://www.tmo.gov.tr/Upload/Document/maliisler/2017faaliyetraporu.pdf. (Erişim tarihi: 20 Kasim, 2018).

Anonim, (2018b). Van İli Uzun Yıllar İklim Verileri. Meteoroloji Genel Müdürlüğü. https://www.mgm.gov.tr/veridegerlendirme/il-ve-ilceler-istatistik.aspx?m=VAN(Erişim tarihi: 27 Kasim, 2018).

Anonim, (2018c). Tarım Kredi Kooperatifleri Van İli Tohumluk Tedarikleri. Tarım Kredi Kooperatifi Genel Müdürlüğü, (Yazılı görüşme: 19 Ekim, 2018)

Anonim, (2018d). Tohumluk Kullanımı Verim Sonuçları. Tohumluk Kullanan 34 Çiftçinin Sonuç Bilgileri (Sözlü görüşme: 01 Kasım, 2018)

Anonim, (2018e). TMO Van İli Buğday Alım Bilgileri Toprak Mahsulleri Ofisi Genel Müdürlüğ̈̈ (Yaz1lı görüssme: 31 Ekim, 2018).

Anonim, (2018f). Van Un Sanayii Buğday Kullanım ve Tercih Durumları. Van Un Fabrikaları Verileri (Sözlü görüşme:21 Kasım, 2018).

Anonim, (2018g). Buğday Destek ve Ödemeleri. Van İl Tarım Orman Müd. (Yazılı görüşme:11 Aralik, 2018).

Anonim, (2018f). Hazineye Ait Tarım Arazilerinin Kullanıcılarına Kiraya Verilmesi İşlemleri El Rehberi. https://www.milliemlak.gov.tr/Documents/Kira/tarim-arazilerinin-kiraya-verilmesibrosur.pdf. (Erişim tarihi: 01 Aralık, 2018).

Briggle, L., Ciba-Geigy, A., Schmidt, J., Laloux, R., Falisse, A., \& Poelaert, J. (1980). "Wheat; documenta Ciba-Geigy."

Briggle, L., \& Curtis, B. (1987). Wheat worldwide. Wheat and wheat improvement (wheatandwheatim), 1-32.

Çimrin, K.M., \& Boysan, S. (2006). Van yöresi tarım topraklarının besin elementi durumları ve bunların bazı toprak özellikleri ile ilişkileri. YYÜ. Tarım Bil. Der., 16(2), 105-111.

Doğan, O., Çöke, K., \& Cimili, B. (1980). Van gölü bölgesinin Tir tarım yönteminin uygulandiğ yörelerde koşullara en uygun buğday çeşidi, tohum miktarl, gübre isteği, toprak hazırlama şekilleri ile Tir mibzerinin geliş̧tirilmesi ve uygun sıra aralı̆̆ının saptanması. M. T. Araştırma and Enstitüsü Müdürlüğü Yayınları, Ankara, Köy İşleri ve Koop. Bak. Genel Yayın No,73,77. 
İpekçioğlu, Ş., Bayraktaş, M.S., Büyükhatipoğlu, Ş., \& Monis, T. (2014). Şanlıurfa ve Mardin illerinde buğday yetiştiriciliği yapan çifţ̧ilerin çeşit seçimindeki bilgi düzeylerinin belirlenmesi. XI. Ulusal Tarım Ekonomisi Kongresi, Samsun, 737-742.

Kaya, B., Nadaroğlu, Y., \& Şimşek, O. (2015). "Türkiye’de toprak sicakliğl yönünden serin iklim tahıllarının ekim zamanının belirlenmesi."

Kaydan, D., Tepe, I., Yağmur, M., \& Yergin, R. (2011). Ekim yöntemi ve sıklığının buğdayda tane verimi, bazı verim öğeleri ve yabancı otlar üzerine etkileri. Tarım Bil. Derg., 1(17), 310-323.

Kaydan, D., \& Yağmur, M. (2007). Van ekolojik koşullarında bazı iki sıralı arpa çeşitlerinin (Hordeum vulgare L. conv. distichon) verim ve verim öğeleri üzerine bir araştırma. Tarım Bilimleri Dergisi, 13(3), 269-278.

Kaydan, D., \& Yağmur, M. (2008). Van ekolojik koşullarında bazı ekmeklik buğday (Triticum aestivum L.) çeşitlerinin verim ve verim öğeleri üzerine bir araştırma. T.B. D., 14(4), 350-358.

Kün, E., Avcı, M., Uzunlu, V., \& Zencirci, N. (1995). Serin iklim tahılları tüketim projeksiyonları ve üretim hedefleri. Türkiye Ziraat Mühendisliği Teknik Kongresi, 9-13.

Leonard, W., \& Martin, J. (1963). Wheat: Importance, history and adaptation. Cereal crops. Macmillian Co., New York, 227-287.

Nuttonson, M.Y. (1955). Wheat-climate relationships and the use of phenology in ascertaining the thermal and photo-thermal requirements of wheat. American Institute Of Crop Ecology; Washington.

Olgun, M., Partigö,ç F., Yıldırım, T, Taçoğlu, M, \& Kumlay, A. (1998). Doğu Anadolu Bölgesinde buğdayın verim potansiyeli. Doğu Anadolu Tarım Kongresi, 14-18.

Olgun, M, Yıldırım, T, \& Partigöç, F. (1999). Doğu Anadolu Bölgesi'nde bazı buğday çeşitlerine ait çeşitli özelliklerin belirlenmesi. Orta Anadolu'da Hububat Tarımının Sorunları ve Çözüm Yolları Sempozyumu, 612-615.

Özberk, İ, Atay, A.S., Cabi, E.E., Özkan, H., \& Atlı, A.A. (2016). Türkiye’nin buğday atlası. İstanbul, WWF-Türkiye.

Özgüven, M.M., Türker, U., \& Beyaz, A. (2010). Türkiye'nin tarımsal yapısı ve mekanizasyon durumu. Gaziosmanpaşa Üniversitesi, Ziraat Fakültesi Dergisi, 2010(2).

Saral, A., Vatandaş, M., Güner, M., Ceylan, M., \& Yenice, T. (2000). Türkiye tarımının makinalaşma durumu. Ziraat Mühendisliği V. Teknik Kongresi, 17-21.

Sönmez, F., Ülker, M., Yılmaz, N., Ege, H., Bürün, B., \& Apak, R. (1999). Tir buğdayında tane verimi ile bazı verim öğeleri arasındaki ilişkiler. Turkish J. of Agricul. and Forestry 23, 45.

Şehirali, S., Gençtan, T., Avcı Birsin, M., Zencirci, N., \& Uçkesen, B. (2000). Türkiye Tahıl ve Yemeklik Tane Baklagil Üretiminin Bugünkü ve Gelecekteki Boyutları.

Yağmur, M., \& Kaydan, D. (2009). The effects of different sowing depth on grain yield and some grain yield components in wheat (Triticum aestivum L.) cultivars under dryland conditions. African J. of Biotechnology, 8(2).

Yılmaz, N. (1989). Van yöresi için uygun buğday çeşidi, ekim zamanı, ekim yöntemi ve bitki sıklığının tesbiti üzerine araştırmalar (Doktora tezi), Ege Üniv.

Yilmaz, N., \& Akyürek, A. (1991). The 'Tir' seeding method and its application in the Van region. Yüzüncü Yll Üniversitesi Tarım Bilimleri Dergisi, 1(3), 170-181.

Yılmaz, N., Ege, H., Ülker, M., \& Sönmez, F. (1994). Bazı kışlık buğday çeşitlerinin Van koşullarına adaptasyonu üzerine bir araştırma. III. Uluslararası Nükleer Tarım ve Hayvancılık Kongresi. Bildiri Özetleri, Ankara, 57. 